\title{
ICONOGRAPHY BETWEEN THEOLOGY AND POLITOLOGY
}

\author{
Ovidiu F. PANAITE*
}

\begin{abstract}
This paper, The Icon as a visual Expression of the Incarnation of Christ, and as a Process viewed in its Articulation with the Byzantine political Reflection, deals with the role and functions of sacred art, particularly of the icon, which has decisively marked the evolution of the Church in the Byzantine political context. The eighth century, through the Seventh Ecumenical Council, was the highlight of this process. On the other hand, this is when the attitude of Christianity to iconographic art was defined by the contributions of important theologians: Saint John of Damascus, Saint Germanus of Constantinople ${ }^{1}$, Saint Nicephorus the Confessor, Saint Theodore of Studium. At the same time, by confirming a dogmatic aspect of the icon, the Church was defending its own nature and identity against the imperial institution, which had entered a process of absorbtion regarding the ecclesial institution. Therefore, the issue was far more complicated, more vast and profound. The support that she provided to the cult of the icons amounted to the independence of the Church from the utilitarian theocracy of the Byzantine Empire. My aim in this paper is to identify the stages of this double effort: on the one hand, the process of establishing the role of the icon in the dogmatic conscienceness of the Church, and on the other hand, the articulation of this dogmatic process as an expression of the independence of the Church in her relationship to Byzantine politology.
\end{abstract}

*PhD, Assistant Professor, "1 Decembrie 1918" University of Alba Iulia (Faculty of Orthodox Theology), Romania.

${ }^{1}$ SAint Germanus I (c. 634-733 or 740), the $39^{\text {th }}$ Patriarch of Constantinople (715-730). He is recognized as a Saint by both the Orthodox and Roman Catholic Churches, feast day on 12 May. There were five patriarchs Germanus of Constantinople, this being the first in cronological order. 
Keywords: Byzantine politology, Iconography, political theology, utilitarian theocracy

\section{Ante scriptum}

Simple or complex. An area marked by uni/ambi or multivalency, by unilateralism or multilateralism: Religion and Politics. The analysis of the relationship between these two subjects, a very controversial binomial, continuously generating concern, engages from the beginning a sensitive speech, richly reflected in literature, sensitivity determined by the spiritual magnitude attached to the stakes of this type of meeting or relationship. At the same time it is necessary to define the terms. What is meant by religion? What is the meaning of policy and the content of the relationship with religion? These are questions too general perhaps, which would engage a more principled speech, at a general level, outdated questions, maybe, in terms of their engagement in the picture of the public discourse, or which assume a certain preciousness, but nevertheless we try to identify the role played by art, specifically the sacred art through icon, in setting up this type of meeting/encunter.

The main issue that arises is related to the understanding, defining and applying the principle of identity when we deal with binomial elements $^{2}$, such as Church - State, modernity - postmodernity, from this perspective, affirming the requirement to identify those elements to keep or preserve the liturgical, sacramental and charismatic ethos of the Church. In this criterion the Orthodox Church and by default the Orthodox faith is the principle of co-naturality. The decrease or the relativization of the principle of co-naturality aims at the construction of a type of areligious Christianity (as Bonhoeffer argued in Widerstand und Ergebung) or at the definition of some secular theological-historical paradigms, an empty historicism.

The dynamic of the relationship between the Empire/State and the Church is not restricted to the purely legal analysis of the institutional

${ }^{2}$ Steven RUNCIMAN introduces a prudent approach to the church-empire relationship in his studies on the Byzantine theocracy, denouncing in the following terms the falsity of the conceptual distinctions between the Church and the Empire: oppositing the Church and the State we make a distinction, which for the Byzantines was a nonsense; and thus we commit a historical and philological error in Byzantine Theocracy, Bucureşti, Nemira, 2012, p. 27. 
interactions such as the legislation, but involves the approach of the political philosophy to Christianity in a wider frame. On the other hand the analysis is determined by the nomination and the identification of the subjects: the relationship between the Empire/State and the Church has a certain content, wheres the relationship between the Church and the Empire/State has other content. From this appreciation we position ourselves in the query of the nature of the first topic: the nature of the State, the political philosophy, the administrative agency, the social, economic policy and we also question the nature of the second subject (the Church): the dogmatic, moral and religious identity. Consequently setting in the frame of the conceptual Empire / State (as a generating subject) we can speak of a political religion. If we refer to the Church, an attitude called political theology is elaborated. There was and still is a whole debate on the concept of political theology. Through the attempt of conceptualization and subsequently of operationalization of the phrase political theology we enter the area of discussions caused by the intersection of several areas of research, belonging to different fields, dominated by the history and philosophy of religion, political science, sociology, anthropology, philosophy and psychology. Therefore, political theology takes the form of a subject with multiple approaches, either as a chapter of cultural anthropology, or as one of political philosophy (Spinoza, Hobbes), or as a subdivision of the history of religions in general or history of Christian religion in particular. In the attempt to understand the entire area covered by this term, more exactly the technical meaning rather than the literal one, we realized the polarization of the debate and the variety of approaches: from researchers who claim the existence and independence of the domain (Carl Schmitt, Johann Baptist Metz, Hans Eger, Jürgen Moltmann, Dorothy Sölle...), to those who deny its existence altogether (Andreas Marxen, Stanley Hauerwas or, Heinrich Meier). Taking into consideration this multitude of approaches, from proposals materialized into individual systems to political-theological constructions of wider impact ${ }^{3}$, with different intentions, from radicalism (such as Clayton Crockett) to neoliberalism, I consider it premature to define a conceptual affiliation to this phrase.

3 Johann Baptist Metz, Jürgen Moltmann, Dorothy Sölle, Leo StRauss, Ernst H. KANTOROWICZ etc. 
Political theology, in our understanding, is defined as an attitude of the Christian consciousness in front of the political-imperial manifesto of authority and all the connected realities deriving from or largely depending on the reference to this imperial or state authority - in a modern sense, confessing a profound spiritual, Christological and pneumatologicalecclesial uncompromising attitude. The topics brought into discussion are grouped around the theological foundations of the Christian view regarding the emperor's person, his politico-religious practice, but also the political philosophy of the Empire with reference to Christianity in general and the Church in particular (the emperor regarded as mimisis, the attributes of a christian emperor, his personal relationship with God, the Church and the emperor, relations with heretics, Judaism and paganism, Christianity and the Empire).

Some works define political theology through its specific method and formal principle, as politics in an extensive meaning ${ }^{4}$, or as the theological-religious view of politics and the political view of religion ${ }^{5}$. Another group of researchers define political theology in regard to its purpose, seeing it as the theological justification of a political system ${ }^{6}$. Another branch of research considers that Christianity has no political theology since the term that best defines the attitude towards the issues of the polis is the term meta-politics. At the same time, having politics as its subject of research is not considered a science in the field of theology, nor a measure of professional therapy for those groups of researchers who

${ }^{4}$ Carl Schmitt, Politische Theologie, Leipzig, 1934, Political Theology, transl. Lavinia STAN and Lucian TurCESCU, Bucureşti, Universal Dalsi, 1996.

${ }^{5}$ Hans EGER, "Die ersten Ansätze zu einer politischen Theologie in der christlichen Kirche", in Deutsche Theologie. Monatschriftfür die deutsche evangelische Kirche, no. 2, Stuttgart, 1935, p. 272-281; IDEM, "Kaiser und Kirche in der Geschichtstheologie Eusebs von Cäsarea", in Zeitschriftfür die neuetestamentlicheWissenschaft und die Kunde der älteren Kirche, no. 38, Berlin, 1939, p. 97-115.

${ }^{6}$ Erik Peterson, Kaiser Augustusim Urteil des antiken Christentums. Ein Beitrag zur Geschichte der politischen Theologie, Kempten-München, 1933, p. 289-299; Hans von CAmPenhausen, Griechische Kirchenväter, Stuttgart, 1961, transl. Maria ANGHELESCU, Părinţii greci ai Bisericii, Bucureşti, Humanitas, 2005. The theological justification of political projects created one of the premises for heresies in the byzantine emperors's attempts to secure the empire's borders. Such a theological framing of political projects led, for instance, to pressures for dogmatization regarding the assimilation of monophysitism in the context of the $5^{\text {th }}$ and $6^{\text {th }}$ Ecumenical Councils. 
desire to create a new conscience, indignant at the corruption of the political act, a political theology of resentment; it means neither the clericalization of politics, nor the politization of religion.

The annalists also present the risks of the secularization of theology based on a one-sided absorption and approach: our dependence on the currents of secularization creates the prerequisites for the risk to politicize theology and transform it into a secular derivation of religiosity, professor Carl Raschkeclaims in a study on the rebirth of what he calls global political theology ${ }^{7}$.

To formulate a type of Christian political philosophy we do not have a biblical repertoire to provide a direct and specific manner of response to this type of problem. The approach is challenging in the sense that involves a variety of factors related to theological motivations or of the other nature of the author, of the attempts to justify theologically the political projects, to politicize religion, the clericalize the politics, trying to find a solution through fragmentary answers built on the political hypostasis of the biblical authors, etc. Theologically, to try one of these statements is to establish as the essential coordinates of speech, the words of Christ. The pharisees trying to prepare a trap for Christ to compromise him before the Roman authority, ask Him whether it is appropriate or not to give tribute to Caesar (Matt. 22:21) But Jesus answered them: "Render therefore unto Caesar the things which are Caesar's; and unto God the things that are God's" (Matt. $22: 21)^{8}$.

It is clear that a Christian assumes a dual series of obligations that are from the two independent autorities and that correspond to the human duality: his body nature, the material nature, on the one hand, and on the other, the spiritual nature. In terms of a conflict between the two the word of Peter applies: we must obey God rather than men. Apostle Paul in Romans chapter 13, 1-5 recommends obedience to the high dominion as what God has appointed, for they are ministers of God for good people. Tertullian makes subtly the difference that we should obey only the legitimate authorities.

${ }^{7}$ Carl RASCHKE, $A$ gamben and the revival of a global political theology - from an economy of resentment to an economy of glory, http://theotherjournal.com/ churchandpomo/2012/03/25..

${ }^{8}$ Nouveau Testament interlineaire grec/francais, Societé Biblique Française, 1993, p. 107. 
As a result, the theological foundations for a political philosophy of Christian inspiration were grouped around major themes developed in the first centuries: it is based on the reality of the Incarnation of Jesus Christ, on the prophetic-apocalyptic manifest of the Church, the power of the transfiguring prayer, the Eucharist profile of the Christian experience held closely by the dogmatic and martyrical conscience of the Church ${ }^{9}$. Later the kings' claim to be both priest and emperor is accompanied by the emergence of popular beliefs about the supernatural powers of the kings. In this respect the pre-feudal German society presents many common points with the pre-civic sacred monarchies of the Antiquity. In this respect Ernst Kantorowitz's researches about the so-called government theology are illustrative.

\section{The political Arianism and the political abstracts from the dogmatic concepts}

The space which will determine concepts such as: the sacreality of the power, the political theology, king and priest, and sacred monarchy etc was the subject that concerns researchers as Keneth M. Setton ${ }^{10}$, Hendrikus Berkhof $^{11}$, Francis Dvornik ${ }^{12}$ etc. A direction of studies was for example, , the period inaugurated by the reign of Constantin cel Mare, the renovatio constantini as an extension of monarchical types of Hellenistic origin, typology built on parallelism between monarchy and monotheism. At the Christianization of the Hellenistic concepts contributed, according to some researchers, largely Eusebius of Caesarea, then the Greek fathers extended the interpretations more extensive conceptual spaces.

${ }^{9}$ See also: *** For the Christianity of the new Europe, Boltzmann series, vol. III, Bucureşti, Humanitas, 2007; Ovidiu PANAITE, Political Theology during the Constantinian dynasty, Alba Iulia, Reîntregirea, 2014.

${ }^{10}$ Kenneth SETTON, The christian attitude towards the Emperor in the fourth century, especially as shown in adresses to the Emperor, German transl. Kirche und Kaiser: Eine Untersuchung der Entstehung der byzantinischen und theokratischen Staatsauffassung im vierten Jahrhundert, New York, Columbia University Press, 1941.

11 Hendrikus BERKHOF, Kirche und Kaiser. Eine Untersuchung der Entstehung der byzantinischen und der theokratischen Staatsauffassung im vierten Jahrhundert, Zürich, 1947.

${ }^{12}$ Early Christian and Byzantine Political Philosophy, Washinton D.C., 1966. 
Michael Azkoul partly agrees with the previous statements ${ }^{13}$. The correction made by Azkoul is the following: the method of a group of modern researchers, a restrictive and positivist one, does not take into consideration the Christological context of patristical political theology. In his view, the Christologic dogma is fundamental in establishing the theoretical foundations of the Church, foundations that become a basis for its reference to civil consciousness. The accusation brought by Azkoul to a historiographical approach is that of having lapsed into a state of ignorance concerning the epistemological and metaphysical evaluation of dogmas. For precisely this docta ignorantia that created the premises for a hermeneutic system which has engendered the idea that renovatio constantini is the continuation of a theocratical Hellenism. Indeed, the Greek Fathers did not develop a stricto senso political philosophy, but they converted Judaic theocracy into a Christian concept ${ }^{14}$. Starting from these prerequisites, A.V. Kartasheff, professor at the Saint Serge Orthodox Theological Institute in Paris, considers that the possibility to understand the Byzantine Christocratic system lies in understanding the mystery of the Incarnation of Christ, more exactly, in accepting the Chalcedon Christologic formula: One and the same Christ, Son, Lord, Only-begotten, made known in two natures [which exist] without confusion, without change, without division, without separation; the distinction of the natures having been in no wise taken away by reason of the union ${ }^{15}$.

This dogmatic formula would become the foundation for the Byzantine symphony during the time of Justinian, a political excerpt from a dogmatic concept, a norm with a very clear political component.

In other words, the Christian kingdom is manifested through Imperium and Sacerdotium, for which there are two natures, according to the two natures of the unique Hypostasis of Christ Our Savior. After this century, political theology is divided in two branches, one of Byzantine

${ }^{13}$ Michael AzKoul, "Sacerdotium et Imperium: the Constantinian Renovatio according to the Greek Fathers", in Theological Studies, no. 32/1971, p. 431-464.

${ }^{14}$ George Florovsky, "Empire and the Desert: Antinomies of Christian History", in Greek Orthodox Theological Review, no. 3/1957, p. 133-159.

15 Actio 5, J.D. MANSI (ed.), Sacrorum conciliorum nova et amplissima collectio 7, Veneţia, 1759), 116 f. in comment by A.V. Kartasheff, The Restoration of Holy Russia, 1946, apud Michael AzKOUL, art. cit., p. 432. 
inspiration and the other of Western, Latin influence ${ }^{16}$.

The apologists or the elements that led to Christian political philosophy, which is why we have appealled to the power of representation of theological literature of the first centuries ${ }^{17}$. In the mixture of religion and politics of the early centuries Christians continued to exist and to organize. This mixture demanded from the Church clearer formulation, shaping and specification of the political philosophy elements of Christian expression. The environment in which such concepts were formulated is marked by the tension that led to the apologetic literature of pagan consciousness and Christian consciousness. Christian inspiration? The dogmatic and martyrical conscienceness of the Church in the first centuries. The exegetical literature and the apologetics will mark the premises of a Christian autonomous political consciousness, as evidenced by the entire epoch of the martyrs ${ }^{18}$.

The first centuries witnessed the process of self-definition of Christianity during the turmoils caused by various heresies. The Arianism also had other implications than those strictly theological. The Aryan theories about the relation of subordination of the Son to the Father, will have a political reflex immediately. In addition to its theological-political aspects of the Arianism we can distinguish some purely theological consequences of the same heresy.

The Arian political theology is based on the principle that the image of God the Father on earth is the emperor, the mundane reflection of the divine monarchy. The same system has a corresponding Son on earth: the Church with the clergy and the believers. If the Son is subordinate to the Father and the Father's image on earth is the imperial power, that the

16 The political augustinianism proposed in 1934 (Henri-Xavier ARQUILLIÈRE, L'augustinisme politique: essai sur la formation des théories politiques du Moyen Âge, Paris, Vrin, 1934), is evaluated by some researchers as an imprecise and ambiguos term. Henry de Lubac challenged (“Augustinisme politique?", in Théologies d'occasion, Paris, Desclée de Brouwer, 1984, p. 255-308) the hystorical pertinence of this concept. Seeinterpretations of Yves Congarwritten in the 1980 ("Le monothéisme politique de l'Antiquité et le Dieu-Trinité", in Concilium no. 163/1981, p. 51-58).

${ }^{17}$ Of major importance are the contributions of Origen (force ideas for the political theology: Resurrection and Christian liberty), Tertullian (reality of the Incarnation of Christ), Clement of Rome (writes the oldest preserved prayer - for the Church leaders).

18 Robert M. GRANT, "The Chronology of the Greek Apologists", in Vigiliae Christianae, 1/1955, p. 25-33. 
Church (clergy and believers) must be subordinated to the empire.

The political application of the Arian theological scheme has therefore the effect of changing the Church in a politicized area where the emperor has ecclesiastical duties. The ecclesial function is determined by the quality of bishop of the bishops, as inspired by this theology, but also by the legacy of a concept of Hellenistic origin, the apotheotic theories of the leader. The Arian emperors will often call this typology stating for example that every wish of the emperor has the same value as a canon, therefore legally compulsory for church: Everything I want has the value of a canon says in 355 the Emperor Constantius in Milan ${ }^{19}$. Following this system, there is the Arian priesthood different from the Nicene priesthood. For the Arians, priesthood has, besides cultic function, a particularly strong political component, functioning as the guarantor of the law.

The Nicene thinking will set another place in the Church for the Emperor. He will not be a bishop of bishops, but a man of the Church. In this respect the phrase episcopos ton ektos means the mission that an emperor assumes to Christianized the space of the civil world.

\section{The sacralisation of power and the Christian symbolism}

To understand certain aspects of iconoclasm and of the Emperor reporting to this theological problem, on the extent permitted by the bibliographic lists, we try syntheticaly an inventory of the historiographical conceptions of the twentieth century ${ }^{20}$, which reflected the iconoclastic phenomenon. The historians' views on this issue are different. Some historians, such as Marx and Walch accepted without a critical analysis all information from chronicles, like the chronicle of Theophanes, attributing to Leon III anti-Christian ideas from Jewish space. Otherwise, during the reign of Leon anti-Jewish propaganda started, forcing them to be baptized in 722 in the strength of a law reactivated during Heraclius ${ }^{21}$. In the

${ }^{19}$ Athanasius, Historia Arianorum, 33, apud Williams HunTson, "Christology and ChurchState relation in the Fourth Century", in Church History, no. 3/1951, p. 3.

${ }^{20} \mathrm{G}$. Ostrogorsky, "Les bases theoriques de la querrele des images a Byzance", in Seminarium Kondakovianum, II, Praga, 1938; Nicolae Iorga, "The Origins of the Iconoclasme", in Buletinul Academiei Române, 1929; G. OstrogORSKY, Studien zur Geschichte des byzantinischen Bilderstreites, Breslau, 1929.

21 TheOPAnEs, a. 6214; Doelger, Reg. 286; cf. F. DvORnIK, Les légendes de Consatntin et 
nineteenth century a historiographical line was outlined by Vasilievsky's studies and by Paparrigopoulos', that stated that the prohibition of images was determined by Leon's major social reforms.

On the other hand, not fully accepting Paparrigopoulos' views that made Leon an enlightened despot after the fashion of the eighteenth century, another category of historians such as Charles Diehl and Nicolae Iorga, still admit that there was an intrinsic connection between political and social reforms of the Empire and the iconoclasme movement. Charles Diehl argues the iconoclastic position of Leon based on strictly personal reasonsof the emperor, paired with elements of Asian education, with Syrian mentality and finally attending a sect that did not admit the cult of icons. However Diehl recognizes Leon as a great politician, with a remarkable social vision. By promulgating the agrarian law, Leon fights against landowners, becoming a champion for the interests of free people. In these conditions it was difficult to discern in the iconoclastic movement what the limit of the popular theology was and what the social interest was. The fact is that the imperial measure taken in 726 to remove the icons from the public spaces discontented the population of Constantinople, the intransigence of some groups turning into hostility ${ }^{22}$.

In support of Diehl's vision, the same chronicle of Theophanes preserves some events attesting the social conflict of the great landowners and the emperor ${ }^{23}$ Leon converting the motivation from a strictly social one, to a theological one. The reason is easy to be identifyed because the repression took new proportions by integrating the monasticism as guilty. The fight was held this time in two directions: against the great seniors and against monasticism, perceived by Leon as an antiprogresist mean that dispossessed the empire of the people for the army, of clerks for the public services, of workers in agriculture and that held in its heritage extended

Méthode, Praga, 1933, p. 201; the anti-jewish controversy during Leon III can be tracked

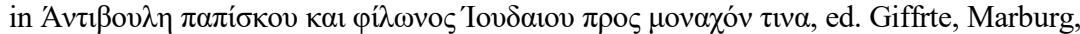
1889, and in Dialogue against Jewish, in P.G., 40, col. 847-866, apud Louis BRÉHIER, "L'hagiographie bzyantine des VIII-e et IX-e sieclés", in Journal des Savants, no. 14/1916, p. 583.

22 TheOPHANES, A.M. 6218, apud Nicolae CHIFĂR, "Byzantine Imperial Power and the Cult of the icons in the eighth century", in Historical Studies, Sibiu, The Publishing House of Lucian Blaga University, 2005, p. 145.

${ }^{23}$ IDEM, A.M., 6257 apud Ibidem. 
possessions of land.

The historiography, by Louis Bréhier ${ }^{24}$, records another observation which allows a better view of the first period of iconoclasm, namely that in Byzantine history some emperors took action directly to limit the development of the monasteries, restricting them by imperial decrees, while no testimony attributes Leon III such measures. However if he did not decrees such decisions, the attitudes and the actions taken showed indirectly the imperial will.

Steven Runciman analyzes the same double duty so typical of the Byzantine world. The role of the political leader as emperor and priest. Leon III worked out the iconoclastic decree based on his authority of Pontifex, as 'emperor and priest', as he told the pope. Runciman grants large spaces of his research to this matter. Emperor Leon III introduced despoticly the iconoclasm of his own will. Constantine V was even more despotic in imposing the doctrine. Runciman asks rhetorically: may iconoclasm be abandoned now without damaging the prestige of the imperial function $2^{25}$ If an emperor-priest was to promulgate a doctrine totally opposed to his predecessor, then it must be something wrong with the priesthood. Maybe it was fortunate case that the despot who decided to restore the cult of icons was not an emperor-priest. The queen mother, Irina, as an august crowned, was recognized as the holder of imperial power and no one questioned her right to be regent for her minor son. But as a woman, she could not be a priest. Her coronation did not include the receiving of the ordaination which an emperor used to receive ${ }^{26}$. So if she would change the religious policy of the empire she had to do it through the Church. By this, the Church achieved a certain constitutional victory, but it was gained at the expense of a woman regent, not of the holy emperor. In this way the iconoclastic literature was very virulent against Irina, the woman emperor.

In the broader context of the empire religion, we distinguish a number of elements that provide additional information to our problem, namely the identification of imperial premises in the triggering of the explicit iconoclasm. In addition to the social measures, Leon brought under

${ }^{24}$ Louis BRÉHIER, art. cit., p. 358-367; p. 450-465.

${ }^{25}$ Steven Runciman, The Byzantine Theocracy..., p. 93.

${ }^{26}$ The term used by Sir Runciman is ordination. The king was allowed to preach, to enter the shrine, to censure, to communicate like the priests, the emperor received a hyrotecy. 


\section{$16^{\text {th }}$ International Symposium on Science, Theology and Arts (ISSTA 2017)}

the relulation the situation of the Jews and Montanists in the empire. Theophane's chronicle attributed to Leon III the edict against the Jews, applied in 722. The information is incomplete, without detailing the issue, the measure being probably brought into connection with the riots caused a year before, in 721, in Palestine where a rabble claimed the title of Messiah $^{27}$. The documents attest that beside the Jewish community, there was a very strong Montanism in Constantinople. The information about this sect is surprising since there are no references from the period of Justinian, the aspect being noticed by A. Scharf. The historian suggests identifying these groups of Montanists with a Jewish sect which would have adopted the Syrian severianisme ${ }^{28}$. Promoting an extremist nationalisme and an eschatological doctrine that led to the dissolution of the Byzantine Empire and the entire Arab world for the return of the Jews to Israel, Montanists tranched upon the integrity of the Empire come to loggerheads with Leon III. Against this background of tension, the edict about the forced baptism of all Jews was issued. Most of the Jewish obeyed, but later they desecrated the Christian mysteries, while the Montanist groups did not accept, preferring to let their members burn imprisoned in a church.

The iconoclastic work of Leon, according to some historians, had begun by publication of an edict in 726 . Certificated only by the Syriac sources this document seems to deny the historical facts. Theophanes' chronicle referring to the events in 726 recalls that this emperor passed into sacrilege and started making speeches about the destruction of the holy images $^{29}$. Meanwhile, the eruption of a submarine volcano was interpreted as a disaster occurred because the veneration of icons. Nichifor's chronicle and St. Stephen's biography are clearer in this regard by developing Leon's speeches and reflecting the hostile reaction of the people when iconographic art was declared idolatrous.

Another argument that supports the lack of an edict in 726 is the assembly convened by the emperor in the autumn of 729 in which the patriarch Herman reproaches Leon: I understand that they say that you want

${ }^{27}$ R. ABRAMOwSKy, "Dyonisios von Tellmahre, jakobitischer Patriarch von 818-845. Zur Geschichte der Kirche unter dem Islam", in Abhandlungen für die Kunde der Morgenlands, no.1/1940; Dionisie de Tell-Mahre, trad. Chabot, Paris, 1885.

${ }^{28}$ A. SHARF, "The Jews, the Montanist and the emperor Len III", in Bizantinische zeitschrift, no. 59/1966.

29 THEOPHANES, a. 6217, apud Louis BRÉHIER, op. cit., p. 596 
to destroy the holy icons; this may not be done by your imperial order ${ }^{30}$. Herman could not have talked with such confidence if that edict had been published. Leon proved great skill in the fight against icons. Knowing people's attachment to them, as an expression of their religiosity, he acted gradually trying to win public opinion before acting persuasively. Because this kind of propaganda did not bring the expected results, Leon ordered the destruction of the icon of Christ from the main entrance of the Sacred Palace, from the Chalke gate. The officer responsible with the removing of the icon is killed along with other dignitaries by a group of pious women. Arrests, convictions, mutilations and exiles followed ${ }^{31}$. The event is the first deliberate iconoclaste act of Leon III the Isaurian.

To avoid rebellions and schisms the emperor tried to get the church endorsed his actions. Therefore he tried to intimidate Gherman, accusing all the Constantinopolitan patriarchs up to that moment of idolatry. Meanwhile they turned their attention to Rome where Pope Gregory II shepherded. Rome answered to Emperor Leo III by two letters and one was addressed to the Patriarch Germanus, letters that constituted as official documents of the theological position of the West against iconoclasme. Although some of them were challenged as apocryphal productions ${ }^{32}$, anyway part of the historiography considers them as authentic. In this regard Ostrogorsky's efforts are remarkable, demonstrating that the editors of the two letters did not use Greek in manuscript found at the National Library in Paris (Graec. 143), document copied with glosses that passed in the text by Palleocappa in the sixteenth century ${ }^{33}$.

The letters exchanged between the pope and the emperor were real

30 THEOPHANES, a. 6221, apud Ibidem.

31 THEOPHANES, a. 6218, and pope Grigorie al II-lea, Scrisoarea către împăratul Leon al IIIlea, la MANSI, Sacrorum Conciliorum nova et amplissima collectio, Florenţa, 1759-1798, reed. Graz, 1960, XII, 956-974, apud Nicolae CHIFĂR, op. cit., p. 145.

${ }^{32}$ L. GuERARD, "Les lettres de Gregoire II à Léon l'Isaurien”, in Melanges d'archéologie et d'histoire, 10, 1890; A. FAGGIOTTO, "Sulla discussa autenticità delle due lettere di Gregorio II a Leone III Isaurico”, in Atti del V Congresso di Studi Bizantini, Roma, 1939; K. Schwartzlosse, Der Bilderstreit. Ein Kampf der grichischen Kirche um ihre Eingenart und ihre Freiheit, Gotha, 1890.

${ }^{33}$ G. Ostrogorsky, "Les debuts de la querelle des images", in Melanges Ch. Diehl, I, Paris, 1930; IDEM, "Uber die vermeintliche Reformtatigkeit der Isaurier", in Bizantinische Zeitschrift, no. 30/1930. 
discourses for and against the holy icons. Leon III, relying on the prerogative that is "emperor and priest" "334 said:

"Those who oppose the canons of the Holy Fathers are anathema. Icons
replace the idols and those who worship them are idolaters. It is not allowed,
as God commanded, to honor what is manmade, any resemblance of those
in heaven and those on earth; demonstrate to me, who taught us to cherish
the things made by human hands and I will accept it as the will of God.
They (the iconodules) worship stones, walls and boards. Like the king of
the Jews, Uzziah who threw the copper serpent out of the temple, after they
had worshipped it for 800 years, so will I take the icons out of the churches
after 800 years. An ecumenical council must be summoned. I will have the
icon of St. Peter from Rome destroyed and Pope Gregory arrested, such as
Constantine (Constantin II) did to Pope Martin." 35

The iconoclastic theory of Leon III in this text is based on the Old Testament prohibition of the Decalogue on the similarities and idols. As he doesn't make any diffrence between two totally different elements Leon causes a great confusion identifying the icon with the idol.

Facing these arguments, Pope Gregory II says that the veneration of icons should not cause a split between people. From this text, the diplomatic attitude of the Pope who wanted a peaceful solution to the problems and not hostility echoes. It further shows the traditional teaching of the Church that the veneration of the icons is in accordance with God's will, that they are desired by God, and consequently manifested by the ecumenical councils that teaches the truth. God forbade only the idols, but $\mathrm{He}$ commanded the making of things to be worshiped in His name: altar table, cherubims and seraphims, the tabernacle of the tables of the law, all the places that manifests the presence of God. We present Lord Jesus Christ in the icons because he became man and therefore we honor the icons of the saints. The divine nature of divinity can not be represented, but only the person of Jesus Christ and the honor rising to the person represented in the icon, to the prototype, how later Saint Theodore Studite would elaborate. Relying that the king can not have clerical powers under which he can

${ }^{34}$ From "The Second Letter to Leon III", the rows 294 and 198 (Gouillard Publishing House), p. 299, apud Nicolae CHIFǍR, "The Religio-political Relations Between Rome and Constantinople at the Beginning of the Seventh Century", in op. cit., p. 165.

${ }^{35}$ From "The Second Letter to Leon III", the row 138 ş.u., apud Ibidem. 
dictatorially interfere in the affairs of the church under the decision that he is emperor and priest, Gregory established himself as did Ambrose of Milan the areas of competence: the dogmas of the Church are not a matter for the king, but for the bishops, because they have the Holy Spirit ${ }^{36}$.

In these conditions the premises of a conflict between the Italian space and Orient outlined. This conflict also had a political component, the Venetians, especially Pentapole area, showing resentment towards the fiscal policyof the the Empire. Intrigues, assassination attempts, plots, a whole system for removing Gregory who still continues to confess his loyalty to the emperor is set in motion. In these circumstances, before making a final decision to outlaw the iconodules (the pope and the patriarch), Leon made a last attempt to convince the East Patriarch Germanus for the iconoclastic cause, during a meeting in the autumn of 729. Failing to win to convince the patriarch, Leon decides to replace him with Anastasius, a close disciple of Gherman's who was seeking the patriarchal honor more than the confession of the truth.

To destroy a tradition with deep roots both in the life of the church and the believers it needed a solemn declaration to establish the level of penalty of the iconodules and outlawing them. Therefore the senate met, that Silentium, on 17 January 730, with the participation of officials who were under the presidency of the emperor. During the works the Patriarch Germanus was invited to sign an iconoclastic statement, but he refused pulling off the episcopal insignia and saying: I am like Jonah, throw me into the sea. I can not confess to another faith, oh emperor, than that of the Ecumenical Council ${ }^{37}$. Consequently, on January 22, Anastasius was established on the Patriarchal Throne of Constantinople as a representative of the theological iconoclasme.

\section{Instead of conclusions}

The chronicles of Theophanes and Nicephorus talk about the systematic aspect of the application of the Edict of January 730, by punishments and excruciations, while Liber Pontificalis testifies about the

${ }^{36}$ Ibidem, p. 69.

37 Theophanes, a. 6221; NiChIFOR, Breviarium, Edit. de Bor, p. 58; Vita Stephani, in PG.100, col. 1058, apud Louis BRÉHIER, op. cit., p. 602. 
beheadings and mutilations, especially among the clergy and the monks, but also among the believers. The application of the edict closely kept track of removing any iconodule sign, of any icons, burn them in the large square of Constantinople. Facing such an iconoclastic offensive, numerous voices arose advocating the legitimacy of the presence of icons in churches. The one who theorized for the first time this issue was St. Ioan Damaschin, providing the Christianity the theological basis of the iconography through the three treaties against the iconoclasts. During this time, in the Occident a meeting against iconoclasme was held under the presidency of Pope Gregory III on November 1 731. The 93 bishops present condemned the heresy setting:

If anyone disregarding the old apostolic tradition kept sacredly in Church, destroys and profanes the holy icons and throws away the icons of our Lord God and Savior Jesus Christ, and of His Immaculate and Glorious Mother, the Ever-Virgin Mary, of the blessed Apostles and of all saints, must be stopped from the Holy Communion with the Body and Blood of our Lord Jesus Christ, and must be excommunicated from the universal Church $^{38}$.

The emperor's reaction was immediate by organizing a military campaign against Rome and by removing Sicily, Calabria and the Oriental Illyria by the jurisdiction of the Occident. This attitude contributed to the estrangement of the relations between Rome and Constantinople, the Occident increasingly turning his attention to the new monarchs of the West.

It is difficult to identify in the legislation of Leon III a well-grounded theological iconoclasme. Here we can find it only as a political tool derived from the social laws in order to reclaim the properties of the monasteries for the empire. This primary type of iconoclasme later supported the conjunction with the imperial Manichean, Nestorian and Monophysite structures leading to the elaborated typology of the iconomachy in the time of Constantin V.

As mentioned in the introduction of this study, the dynamic relationship between the Empire/State and the Church was not reduced to the analysis of the institutional strictly legal interactions as law cases, but

${ }^{38}$ L. DuCHESNE (ed.), Liber Pontificalis, I, Paris, 1886, 415 s.q., apud Nicolae CHIFĂR, The Imperial Power..., p. 146. 
they involved and involve the aproach of the political philosophy to Christianity in a wider frame. On the other hand the analysis is determined by the nomination and the identification of the subjects: the relationship between the Empire/State and the Church has certain content, wheres the relationship between the Church and the Empire/State has other content. From this appreciation we position ourselves in the query of the nature of the first topic: the nature of the State, the political philosophy, the administrative agency, the social, economic policy and we also question the nature of the second subject (the Church): the dogmatic, moral and religious identity. It is from this perspective that the difficulty of the iconoclasme approach emerges.

\section{References}

1. BRÉHIER, Louis, "L'hagiographie bzyantine des VIII-e et IX-e sieclés", in Journal des Savants, no. 14/1916.

2. FIKRET, Yegül, K., "A Study in Architectural Iconography: Kaisersaal and the Imperial Cult", in The Art Bulletin, vol. 64, no. 1/1982.

3. HunTSON, Williams, G., "Christology and Church-State relation in the Fourth Century", in Church History, no. 3/1951.

4. PAnaITE Ovidiu, Political Theology during the Constantinian dynasty, Alba Iulia, Reîntregirea, 2014.

5. Runciman, Steven, Byzantine Theocracy, Bucureşti, Nemira, 2012.

6. SCHMITT, Karl, Politische Theologie, Leipzig, 1934.

7. YARBro, Adela Collins, "Mark and His Readers: The Son of God among Greeks and Romans", in The Harvard Theological Review, no. 2/2000.

8. ZeITLER, Barbara, "The icons of Their Bodies: Saints and their Images in Byzantium", in American Journal of Archaeology, no. 2/1998.

9. IDEM, "Visual Polemics in the Ninth-Century Byzantine Psalters", in Speculum, no. 4/1994. 